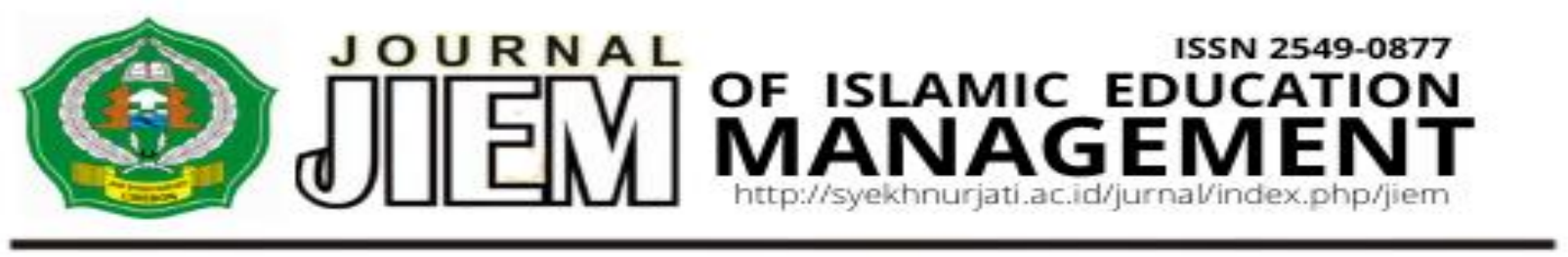

\title{
MANAJEMEN STRATEGIK DALAM PENINGKATAN KUALITAS PENDIDIKAN DI SEKOLAH MENENGAH ATAS NEGERI 1 METRO LAMPUNG STRATEGIC MANAGEMENT IN IMPROVING THE QUALITY OF EDUCATION IN THE STATE SENIOR HIGH SCHOOL 1 METRO LAMPUNG
}

\author{
Oki Dermawan \\ Universitas Islam Negeri Raden Intan Lampung \\ Email: okidermawan@radenintan.ac.id
}

\begin{abstract}
ABSTRAK
Pendidikan berkualitas bisa terwujud jika sekolah menerapkan manajemen strategik dengan benar. Berdasarkan pandangan ini, permasalahan lemahnya mutu sekolah ini terletak pada belum maksimalnya penerapan manajemen strategik. Untuk itu penulis tertarik melakukan penelitian dengan maksud untuk mengungkap secara mendalam penerapan manajemen strategik dalam upaya meningkatkan kualitas pendidikan di SMAN 1 Metro Lampung. Penelitian ini adalah penelitian deskriptif kualitatif. Subyek penelitian ialah kepala sekolah, wakil kepala sekolah, guru, staf, dan komite sekolah. Teknik pengumpulan data dilaksanakan dengan wawancara mendalam, observasi mendalam, dan studi dokumentasi. Hasil penelitian memperlihatkan bahwa sekolah ini merencanakan manajemen strategik melalui perumusan visi, misi, tujuan, dan sasaran. Penerapan manajemen strategik dilaksanakan melalui peningkatan mutu program pendidikan, kegiatan lingkungan internal dan eksternal sekolah, budaya sekolah, penanaman norma dan pembiasaan. Pelaksanaan evaluasi dilaksanakan melalui sejumlah pertemuan dinas melibatkan manajemen puncak dan semua personil sekolah dan masyarakat baik jangka pendek, menengah dan panjang untuk meningkatkan kualitas pendidikan.
\end{abstract}

Kata kunci: Manajemen Strategik, Peningkatan Mutu Pendidikan

\begin{abstract}
Quality education can be realized if schools implement strategic management properly. Based on this view, the weak quality of the school is caused by the inadequate application of strategic management. For this reason, I was interested in researching to reveal in-depth the application of strategic management to improve the quality of education at State Senior High School 1 Lampung. This research was a descriptive qualitative research. The research subjects were the principal, viceprincipal, teachers, staffs, and school committees. Data collection techniques were carried out by indepth interviews, in-depth observation, and study of documentation. The results showed that this school planned strategic management through the formulation of vision, mission, goals, and targets. The implementation of strategic management was carried out through improving the quality of educational programs, school internal and external environmental activities, school culture, norms and habituation. The evaluation was carried out through official meetings involving top management and all school and community personnel, both short, medium and long term to improve the quality of education.
\end{abstract}


Keywords: Strategic Management, Education Quality Improvement

\section{PENDAHULUAN}

Dewasa ini, pendidikan sedang menjadi fokus perhatian seluruh komponen bangsa ini, sebab pendidikan adalah faktor penting bagi perkembangan kemajuan suatu masyarakat dan bangsa. Pendidikan adalah proses guna memperbaiki, meningkatkan, mengubah sikap, tingkah laku, keterampilan, dan pengetahuan seseorang dalam upaya mencerdaskan kehidupan manusia melalui aktivitas bimbingan, penelitian, dan pengajaran (Syah, 2004: 10). Proses pendidikan memperlihatkan adanya kegiatan dalam wujud tindakan aktif melalui sejumlah interaksi yang dinamis dan dilaksanakan secara sadar dalam upaya mencapai tujuan yang diharapkan. Untuk itu, tindakan pendidikan senantiasa bersifat terencana dan aktif, maka pendidikan adalah suatu tindakan yang dilaksanakan secara sadar dalam rangka perubahan sikap dan tingkah laku yang diharapkan, yakni terjadinya pemanusiaan manusia yang mandiri, berdisplin, terampil, berakhlak mulia, dan cerdas.

Pusat perhatian yang dimaksud terlihat dari Undang-Undang sistem pendidikan No. 02 tahun 1989 menjadi Nomor 20 tahun 2003, diiringi peraturan pemerintah No. 32 tahun 2013 mengenai Standar Nasional Pendidikan. Panduan teknis Nasional Pendidikan (SNP) ialah kriteria minimal tentang sistem pendidikan di semua wilayah hukum Negara Kesatuan Republik Indonesia, yang meliputi 8 standar, yakni: standar isi, standar proses, standar pembiayaan, standar pengelolaan, standar sarana dan prasarana, standar pendidik dan tenaga kependidikan, standar kompetensi lulusan, dan standar penilaian pendidikan.

Kunci sukses yang mesti dimiliki dan sekaligus juga merupakan daya saing yang paling ampuh ialah mutu. Siapapun yang mempunyai mutu, maka kesempatan untuk bisa memenangkan persaingan sangat terbuka lebar (Pournasir, 2013: 65-78; Nuryakin, 2018:3). Dalam dunia pendidikan, persaingan merupakan hal yang wajar. Lahirnya persaingan itu ialah guna memperoleh obyek pendidikan atau peserta didik yang sebanyakbanyaknya. Dengan demikian, lazimnya hanya pimpinan lembaga pendidikan yang memiliki mental tangguh yang dapat menghadapi ketatnya persaingan antar lembaga pendidikan. Tidak heran jika kualitas pendidikan menjadi diantara tema sentral yang menyedot perhatian dalam banyak diskusi, seminar, worshop tentang pendidikan di Indonesia dewasa ini. Tema ini akan semakin menarik manakala dikaitkan dengan persaingan global memasuki era milenium ketiga ini.

Paradigma globalisasi sebagai hasil perkembangan kemajuan ilmu pengetahuan dan teknologi, terutama teknologi informasi, adalah wujud dari kelanjutan modernisasi (He, 2011: 3). Globalisasi sebagai masa yang secara esensi mengarah kepada perkembangan yang sangat cepat dalam bidang informasi, komunikasi, transformasi, dan teknologi yang dapat membawa berbagai aspek kehidupan manusia berubah, dunia menyempit, yang jauh menjadi sesuatu hal dapat dijangkau dengan mudah (Archibugi dan Pietrobelli, 2003: 861-862).

Pendidikan adalah suatu investasi utama dalam mendesain pola kehidupan manusia di masa yang akan datang. Hal ini beralasan, karena melalui invetasi pendidikan, manusia mempunyai tiga keuntungan, yaitu (1) pendidikan sebagai usaha yang mengarah kepada pembentukan sosok manusia yang berkualitas secara intelektual melalui proses pembelajaran (Adam dan Negara, 2015: 92; Rustiadia, 2015: 378-386). (2) Pendidikan adalah usaha pembentukan masyarakat yang berwatak, beretika dan berestetika melalui proses penanaman nilai-nilai yang termuat di dalamnya. (3) Pendidikan adalah salah satu garansi untuk mendapatkan derajat yang tinggi dan kehidupan yang lebih baik (Q.S. alMujadalah: 11), baik secara material ataupun transcendental. Dengan argumentasi inilah, pendidikan secara serta merta memiliki arti yang sangat penting dan strategis dalam JIEM (Journal of Islamic Education Manajemen) Vol. 4 No.1 ISSN 2549-0877 
memajukan kehidupan manusia ke depan yang seimbang dan berkualitas (Ionescu, et al, 2013: 141-158; Idrisa, et al, 2012: 443 -450; Edgerton, et al, 2012: 265-296).

Walaupun begitu, ada sejumlah faktor yang bisa diimplementasikan oleh sekolah sehingga mutu output pendidikan bisa menjawab harapan masyarakat, yakni manusia yang berilmu pengetahuan dan teknologi serta beriman yang kokoh. Untuk mencapai harapan masyarakat dan membangun mutu pendidikan dibutuhkan penerapan manajemen strategik dalam manajemen pendidikan di sekolah (Yaakob, 2019: 1-6).

Manajemen pendidikan harus diterapkan dengan baik sejalan dengan perkembangan zaman. Artinya seluruh sumber daya yang memberikan dampak pada semua proses pendidikan harus diatasi secara terencana, terkendali, terarah, dan terorganisir. Dari konteks inilah maka sekolah dituntut mempunyai kompetensi manajerial, yaitu kemampuan menciptakan pola kerja yang strategis, realistis sistematis, dan logis. Lebih jauh lagi, dengan meningkatnya daya saing dan tuntutan perubahan disebabkan kuatnya arus globalisasi, maka implementasi manajemen strategik menjadi suatu keniscayaan, khususnya di institusi pendidikan.

Melalui penerapan manajemen strategik, institusi pendidikan dapat bersaing, bisa meningkatkan mutu layanan pendidikan, dan dapat mengantisipasi dinamika perubahan. Pengelolaan pendidikan yang diimplementasikan di lingkungan internal sistem pendidikan formal hanyalah sebagian dari tanggungjawab pihak pimpinan sebagai manajer pendidikan. Para manajer pendidikan, yaitu kepala sekolah sebagai eksekutif belum bisa mengamati dan menjawab semua tantangan lingkungan eksternal baik yang dekat ataupun yang jauh. Lingkungan eksternal dekat ialah lingkungan yang memiliki pengaruh secara langsung terhadap operasional sekolah, seperti sejumlah potensi dan situasi dalam bidang pendidikan yang menjadi fokus program sekolah itu sendiri, kondisi persaingan, keadaan pelanggan pendidikan, dan pengguna lulusan. Seluruhnya berdampak kepada penetapan strategi yang dinilai mendukung sekolah dalam mencapai tujuannya. Lingkungan eksternal yang jauh ialah kekuatan-kekuatan dan situasi yang lahir dari luar lingkungan eksternal yang dekat menyangkut tantangan global, perkembangan teknologi, keamanan nasional, politik, dan kondisi sosial ekonomi. Secara tidak langsung berpengaruh terhadap pelaksanaan sistem pendidikan di suatu lembaga pendidikan.

Manajemen strategik merupakan aktivitas yang mesti dilaksanakan oleh manajemen puncak bersama segenap sumber daya manusianya secara berkesinambungan, dan merupakan siklus yang dapat menghasilkan keputusan untuk menjawab relevansi keperluan organisasi dengan keperluan lingkungan (Murniati dan Usman, 2008: 74). Dalam konteks sekarang, melalui manajemen strategik, pimpinan tertinggi dalam suatu organisasi, khususnya organisasi pendidikan, mesti dapat memformulasikan dan menetapkan strategi organisasi yang benar sehingga organisasi yang tersebut tidak saja dapat mempertahankan eksistensinya, namun pula kuat dalam melakukan adaptasi dan inovasi yang dibutuhkan sehingga organisasi semakin dapat meningkat produktivitas dan efektivitasnya (Walker, 2010: 367-386).

Terdapat sejumlah persoalan yang menarik perhatian penulis untuk melaksanakan studi mengenai penerapan manajemen strategik untuk meningkatkan kualitas pendidikan. Pertama, rendahnya daya saing sekolah dan kualitas pendidikan di Indonesia. Berpijak pada data Education for All (EFA) Global Monitoring Report yang dirilis UNESCO pada tahun 2011, indeks pembangunan pendidikan Indonesia sebesar 0,934 sehingga memposisikan Indonesia di 69 dari 127 negara di dunia (Runtuwene, 2013:1). Lebih dari itu, data Balitbang menjelaskan bahwa pada level Sekolah Menengah Atas hanya ada tujuh sekolah yang mendapatkan pengakuan dunia sebagai The 
Diploma Program dari 8.036 Sekolah Menengah Atas yang ada di Indonesia (Kulsum, 2013:1).

Hal tersebut memperlihatkan bahwa pendidikan di Indonesia masih dikatagorikan rendah sehingga dibutuhkan usaha peningkatan kualitas pendidikan. Sekolah menghadapi tantangan dan perkembangan globalisasi dimana tantangan tersebut menyangkut efek kompetisi dan globalisasi. Dengan memperhatikan fenomena persaingan dan perkembangan antar sekolah yang semakin meningkat tersebut, sekolah dituntut untuk bisa mengimplementasikan sejumlah strategi unggulan dalam merespon pesaing. Manajemen strategik adalah diantara alternatif tepat dalam menghadapi persoalan tersebut, sebab manajemen strategik adalah manajemen yang mengarah ke masa depan dan berlandaskan pada analisis lingkungan internal dan eksternal. Melalui proses tahaptahap manajemen strategik, sekolah bisa memperhitungkan keputusan, tindak lanjut dan pilihan strategi yang benar dalam menghadapi perubahan dan perkembangan kondisi pendidikan.

Kedua, munculnya anggapan bahwa dengan adanya pergantian pimpinan, maka kinerja sekolah semestinya berubah. Implementasi manajemen strategik menawarkan pemecahan masalah dalam mengamati, mengelola, dan mengevaluasi seberapa jauh efektif dan efesien suatu sekolah bekerja dalam mencapai kinerja dan tujuan organisasi secara sinergis dan sistematis seperti menjawab pertanyaan mengapa suatu sekolah gagal dan sukses dalam manajemen sekolah, mengapa dengan menghadapi lingkungan sekolah yang sama, namun sekolah memperlihatkan kinerja dan prestasi yang berbeda, dan mengapa dengan kepemimpinan yang tidak sama memperlihatkan kinerja yang tidak sama pula dalam manajemen sekolah.

Dalam konteks manajemen strategik, kepala sekolah harus merefleksikan peran koordinatif, sebagai pengambil keputusan dan fasilitator yang tepat terhadap program strategik sekolah yang dilaksanakan oleh tim dalam jangka waktu tertentu baik jangka pendek, menengah, dan panjang sehingga perencanaan yang sudah dibuat bisa dilaksanakan dengan baik. Hubungan antara perencanaan, penerapan dan evaluasi strategik lintas pimpinan saling berkaitan dan tidak bisa berdiri sendiri, ada tahapan sistematis yang mesti dilaksanakan sekolah sejalan dengan program yang sudah dan hendak ditetapkan sehingga bisa meminimalkan potensi kemunduran kinerja sekolah dengan pergantian pimpinan.

Ketiga, meningkatnya jumlah sekolahsekolah unggulan yang ada di Indonesia. Persaingan dalam dunia pendidikan yang sangat pesat ini berpengaruh terhadap peningkatan jumlah sekolah unggul yang tersebar di Indonesia, termasuk di Lampung. Diantaranya ialah keberadaan SMA Negeri 1 Metro sebagai sekolah unggul di Propinsi Lampung. SMA Negeri 1 Metro adalah diantara sekolah unggul yang pernah dikategorikan sebagai sekolah berpredikat Rintisan Sekolah Bertaraf Internasional, atau disingkat RSBI. Di tingkat nasional, sekolah ini pernah menjadi duta olimpiade sains mewakili Provinsi Lampung.

\section{METODE}

Penelitian ini adalah penelitian diskriptif, yakni suatu penelitian yang hanya menggambarkan dan memaparkan dengan jelas mengenai keadaan penelitian dilakukan, serta mendeskripsikan variabel atau keadaan di lapangan dalam suatu keadaan tertentu (Kurniawan, 2018: 29-30). Dalam penelitian ini, sangat memungkinkan peneliti untuk mengumpulkan informasi yang terperinci dan kaya yang meliputi dimensi sebuah kasus. Penelitian ini adalah penelitian lapangan studi kasus, sebab penelitian ini diarahkan untuk memahami sejumlah fenomena yang berhubungan dengan rumusan masalah pada suatu kasus di SMAN 1 Metro Lampung. Penelitian ini sudah dilakukan mulai tanggal 15 Maret 2019 sampai dengan 30 November 2019 bertempat di SMAN 1 Metro Lampung. Informan atau subyek utama dalam penelitian ini ialah kepala sekolah, wakil kepala sekolah, bendahara sekolah, guru-guru, tenaga tata 
usaha, dan komite sekolah di SMAN 10 Fajar Harapan. Metode pengumpulan data dilakukan melalui wawancara mendalam, observasi mendalam, dan teknik dokumentasi. Analisis data dilakukan melalui pencarian dan penataan secara sistematis hasil wawancara mendalam, observasi mendalam, dan dokumentasi dengan cara reduksi data, penyajian data, dan penarikan kesimpulan.

HASIL DAN PEMBAHASAN

Perencanaan Strategik dalam Meningkatkan Mutu Pendidikan

Perencanaan strategik merupakan taktik dan cara utama yang didesain secara sistematik dalam menjalankan fungsi manajemen yang berorientasi pada tujuan strategik organisasi. Perencanaan strategik adalah bagian yang penting dari manajemen strategik. Perencanaan strategik adalah aspek penting dalam manajemen strategik dan bisa dinilai sebagai pilar sentral dalam manajemen strategik.

Manajemen strategik merupakan proses formulasi dan penerapan rencana dan aktivitas-aktivitas yang berkaitan dengan berbagai hal penting, bisa menembus, dan terus menerus bagi suatu organisasi secara keseluruhan. Strategi yang dipakai dalam manajemen sekolah dikelola sedemikian rupa, yakni perencanaan strategik sekolah berhubungan dengan operasi sekolah dalam melaksanakan programnya, sedangkan untuk memperkuat kemampuan sekolah menghindari permasalahan dan bisa mencapai tujuan sejalan kualitas yang dipersyaratkan, maka akan diuji kompetensi kepala sekolah menetapkan kebijakan. Manajemen strategik ialah suatu pendekatan sistematis guna meningkatkan tanggungjawab manajemen, mengkondisikan organisasi pada situasi yang tepat dalam mencapai tujuan dengan cara yang meyakinkan keberhasilan dan terus menerus serta menjadikan sekolah menjadi surprise (Sagala, 2007).

Proses perencanaan strategik menjadi beberapa langkah, yang mengarah kepada tindakan, hasil, dan evaluasi, yaitu: (1) memprakarsai dan menyetujui suatu proses perencanaan strategis, (2) memperjelas mandat organisasi, (3) memperjelas misi dan beberapa nilai organisasi, (4) menilai lingkungan eksternal, (5) menilai lingkungan internal, (6) mengidentifikasi isu strategis yang ditemui organisasi, (7) merumuskan strategi untuk mengelola isu-isu, (8) menyusun visi organisasi yang efektif untuk masa depan, (9) mengembangkan proses implementasi, (10) menilai kembali strategi dan proses perencanaan strategis (Bryson, 1998: 23).

Perencanaan strategik di SMAN 1 Metro Lampung dilakukan dari sejumlah perencanaan yang dinilai lebih menguntungkan dan disetujui bersama oleh kepala sekolah bersama timnya dengan melengkapi berbagai unsur yang berkompeten di bidangnya. Penentuan visi dan misi yang jelas, singkat dan selaras dengan perubahan kebijakan pemerintah. Perencanaan strategik tersebut dilaksanakan dengan sejumlah aktivitas, yaitu: pembentukan tim penyusun visi misi agar secara intensif bisa merealisasikan perencanaan secara optimal. SMAN 1 Metro Lampung memanfaatkan forum rapat kerja untuk menyusun strategi terbaik.

Visi misi adalah konsep perencanaan yang diiringi tindakan sejalan dengan rencana yang sudah diformulasikan untuk mencapai tujuan. Penyusunan visi dan misi yang dilaksanakan oleh tim penyusunan dilaksanakan dengan menselaraskan visi dan misi yang sudah ada dengan situsi dan kondisi atau perkembangan zaman. Hal ini dilaksanakan agar visi dan misi yang dirumuskan senantiasa diperbaharui. Hasil penilaian lingkungan merupakan sejumlah peluang yang mesti digunakan oleh organisasi dan ancaman yang harus dicegah atau dihindari. Secara tidak langsung sudah dilaksanakan pula analisis peluang dan ancaman bagi sekolah.

Adapun pernyataan visi SMAN Metro 1 Lampung ialah "Disiplin, Unggul, Dilandasi Iman dan Taqwa (Digul Imtaq)". Apabila ditelaah dari konsep bahasa, kata disiplin dan unggul dimaknai sebagai aksi-aksi yang konsisten dengan aturan dan nilai lebih yang 
dimunculkan sehingga membedakannya dengan institusi secara umum. Sedangkan konsep dilandasi iman dan taqwa bisa dimaknai sebagai penciptaan nilai iman dan taqwa dalam seluruh kegiatan pendidikan dan lingkungan sekolah diiringi oleh keteladan. Secara konseptual, terdapat sejumlah indikator yang mesti dipenuhi untuk merealisasikan tujuan visi tersebut. Unggul secara lembaga, artinya secara umum unggul dalam program-program pendidikan tentunya harus dibuktikan dengan diraihnya prestasi akademik dan non akademik oleh sekolah lebih baik dari rata-rata sekolah-sekolah menengah atas. Apabila ditelaah secara garis besar berlandaskan temuan data prestasi sekolah dan kedisiplinan pendidikan di sana, SMAN 1 Metro Lampung sudah memenuhi indikator disiplin dan unggul. Hal ini dibuktikan dengan sederet prestasi pada tingkat nasional bahkan internasional. Dua peserta didik SMA Negeri 1 Metro, yakni Ansori Muchtar berpartisipasi dalam pelatihan siswa 15 besar nasional pada tanggal 4 April sampai dengan 3 Mei 2010 di Institut Teknologi Bandung untuk seleksi Tim ICHO yang akan meluluskan 6 orang untuk kemudian mengikuti seleksi ICHO di Jepang. SMAN 1 Metro dikenal dengan menjadi duta olimpiade sains mewakili Provinsi Lampung. Olimpiade mata pelajaran yang sampai saat ini senantiasa menjadi juara 1 di Lampung, yakni olimpiade kimia. SMAN 1 Metro pertama kali berpartisipasi di olimpiade kimia pada tahun 2002 dan sampai ke level nasional yang diwakili Nurdin Riyanto. Tahun 2018 peserta didik SMAN 1 Metro kembali menyumbangkan satu medali untuk Indonesia pada Olimpiade Kimia Internasional ke-50 yang diselenggarakan di Praha (Ceko) dan Bratislava (Slovakia) 19 sampai 29 Juli 2018. Lebih jauh lagi, sekolah ini menurut versi Kemendikbud termasuk salah satu sekolah terbaik di Indonesia (dokumentasi administrasi sekolah 2019). Sekolah inipun pernah menyandang sekolah bertarap internasional. Meskipun sistem sekolah bertarap internasional ini ditiadakan oleh Mahkamah Konstitusi pada 2012, SMA
Negeri 1 Metro tetap menjaga kualitas pendidikannya dengan menjalankan tuntutan Kurikulum 2013 untuk kelas 10. Selanjutnya, dilandasi iman dan taqwa sudah dicerminkan dari pembiasaan shalat berjamaah, keteladanan dan rutinintas.

SMAN 1 Metro Lampung memanfaatkan prestasi peserta didik yang senantiasa meningkat, lulusan yang dihasilkan senantiasa diterima di perguruan tinggi favorit, Sumber Daya Manusia yang dimiliki sangat berkompeten, lingkungan yang kondusif, dan sarana prasarana yang cukup memadai sebagai suatu kekuatan untuk merealisasikan visi dan misi yang disusun.

Sesudah visi dan misi disusun, aktivitas berikutnya yang ditempuh ialah menetapkan tujuan dan target, yaitu penyusunan rencana jangka panjang yang hendak dilakukan dalam kurun waktu empat tahunan juga rencana tahunan yang dirancang setiap awal tahun. Akdon menegaskan bahwa sasaran/target organisasi sangat penting, sebab adalah diantara tonggak dari proses formulasi perencanaan strategik yang efektif yang mendukung masing-masing butir tujuan dan menyatakan sejumlah tugas khusus yang diselesaikan dalam jangka waktu pendek apabila organisasi ingin sukses (Akdon, 2011:146). Peningkatan pembelajaran secara berkenimbungan dilaksanakan agar bisa melampaui standar ketuntasan lulusan.

Untuk mendukung moving class program, SMA Negeri 1 Metro mempunyai Kelas Umum (General Subjects Class), Kelas Seni (Art Class), Kelas Agama (Religion Class), Kelas Bahasa (Languages Class), Kelas Matematika (Mathematics Class), Kelas Sosial (Social Class), Kelas Biologi (Biology Class), Kelas Fisika (Physics Class), Kelas Kimia (Chemistry Class), Lab. Komputer (Computer Laboratorium), Lab. Kimia (Chemistry Laboratorium), Lab. Fisika (Physics Laboratorium), Lab. Bahasa (Language Laboratorium). Peningkatan kualitas pendidik juga senantiasa direncanakan dalam setiap perencanaan tahunan. 
Analisis kekuatan, kelemahan, peluang dan ancaman dari masyarakat serta hambatanhambatan yang terjadi sampai alternatif pemecahan masalah belum disusun dalam dokumen analisis. Pengadaan sarana parasana sudah direncanakan untuk peningkatan kualitas belajar, serta peningkatan kualitas pendidik agar kualitas pendidikan bisa tercapai.

Sejalan dengan hasil penelitian Khan dan Khalique menerangkan bahwa perumusan strategi memperlihatkan cita-cita dan tujuan organisasi yang sesungguhnya. Pada konteks ini, organisasi mesti menyusun visi, misi, nilai, menelaah lingkungan internal dan eksternal, serta menarik kesimpulan analisis faktor internal dan eksternal (Khan dan Khalique, 2014: 165-182).

Penerapan Manajemen Strategik dalam Meningkatkan Mutu Pendidikan

Penerapan strategi merupakan proses manajemen merealisasikan strateginya dalam wujud anggaran, prosedur, program, dan pengembangan strategi dalam wujud tindakan. Penentuan visi dan misi juga dilaksanakan jika dipandang telah tidak relevan. Visi adalah suatu proses yang mendeskripsikan sejumlah aktivitas perencanaan dan penetapan target sekolah secara formal dan misi ialah alasan eksistensi suatu lembaga (Gurley, 2014: 1-46). Strategi ialah sebuah rencana yang komprehensif memadukan berbagai sumber daya dan kemampuan yang memiliki tujuan jangka panjang guna memenangkan kompetisi. Betapapun hebatnya suatu visi, misi, dan strategi jika tidak diterapkan tentu saja strategi itu tidak akan berarti bagi peningkatan mutu sekolah.

Proses manajemen strategik meliputi beberapa tahap: (1) Analisa lingkungan, (2) menetapkan visi, misi, dan tujuan, (3) formulasi strategi, (4) penerapan strategi, dan (5) evaluasi strategi. Penerapan strategik di SMAN 1 Metro Lampung dilaksanakan melalui tim perumus meliputi kepala sekolah, wakil kepala, 2 orang guru dan komite sekolah. Formulasi visi dan misi diformulasikan dengan memakai kalimat yang singkat dan jelas sehingga mudah difahami tolak ukur yang diinginkan. Analisis kekuatan, kelemahan, peluang dan ancaman dari lingkungan didiskusikan dalam pertemuan atau rapat interen sebagai landasan menetapkan kebijakan. Analisis peluang peserta didik diketahui banyak dari masyarakat. Harapan-harapan masyarakat di luar sistem tersebut merupakan database yang berisi informasi mengenai past performance, the current situation, and the future, yang ditindaklanjuti dalam analisis SWOT. Sementara itu, animo masyarakat yang sangat besar dan persaingan yang ketat antar sekolah dijadikan sebagai suatu peluang untuk terus maju demi merealisasikan visi dan misi.

Dalam penerapan strategi yang sudah dirumuskan, SMAN 1 Metro Lampung merumuskan beberapa kegiatan. Teknis implementasi sejumlah kegiatan tersebut diserahkan kepada koordinator masingmasing. Dalam penerapannya, kepala sekolah menggunakan sistem pengawasan dengan membangun komunikasi secara intensif dengan koordinator setiap kegiatan. Sistem lain yang dilaksanakan oleh kepala sekolah SMAN 1 Metro Lampung ialah dengan melaksanakan pengamatan, pengawasan, dan pengecekan secara rutin dan berkala. Sistem pengawasan yang digunakan oleh kepala sekolah SMAN 1 Metro Lampung bervariasi. Sesekali dengan terjun langsung ke lapangan, sesekali pula melalui upacara pagi atau dengan menemui wakil-wakil kepala sekolah dan koordinator kegiatan.

Lebih lanjut, terkait dengan iklim dan budaya sekolah dalam penerapan manajemen strategik. Dalam hal ini, SMAN 1 Metro Lampung sudah menciptakan budaya peserta didik yang baik, yakni berupa lingkungan pembelajar, penanaman nilai-nilai moral iman dan taqwa, program pembiasaan dan keteladanan yang dibangun dalam keseharian kegiatan pendidikan di sekolah. Sedangkan budaya kerja tenaga kependidikan dan pendidik SMAN 1 Metro Lampung sudah dinilai baik, setiap karyawan dan guru melakukan tugas dan tanggungjawab masingmasing dan ditumbuhkembangkan budaya 
profesional dalam bertugas yang mengharuskan para pegawai sekolah untuk aktif bekerja secara optimal.

Aspek budaya juga mempunyai peran dalam penerapan strategik. Marquardt (Usman, 2013:214) menjelaskan bahwa "semua organisasi mempunyai budaya yang meliputi sejumlah ritual, kepribadian, norma, kebiasaan, nilai, sikap, keyakinan, dan kecintaan bersama terhadap organisasi. Peran budaya dalam penerapan manajemen strategik sangat besar dalam mencapai kesuksesan penrapannya. Keberhasilan suatu organisasi ditentukan oleh seberapa besar dukungan lingkungan yang didapatkan strategi dari budaya organisasi.

Berpijak pada hasil penelitian, sekolah mengimplementasikan sejumlah kebijakan seperti tata tertib sekolah, jadwal pelajaran dan pengajaran, kalender pendidikan, kebijakan cuti pegawai dan sebagainya. Rohman (2012:108) menjelaskan bahwa kebijakan pendidikan adalah kebijakan publik yang mengatur secara khusus regulasi berhubungan dengan penyerapan sumber, alokasi, distribusi sumber, dan pengaturan perilaku dalam pendidikan. Berpijak pada penjelasan ini bisa diuraikan bahwa kebijakan menyatakan pengaturan perilaku yang dibuat untuk menjamin keberhasilan strategi yang diterapkan.

Rencana jangka panjang dibuat untuk 4 tahun pertama, sementara itu rencana tahunan telah diformulasi secara tertib setiap permulaan tahun. Peningkatan pembelajaran dengan efektif, dan efisien terus dilaksanakan dengan dan membuka kelas Bilingual. Peningkatan kualitas pendidik dengan menyusun perangkat pembelajaran kelas $\mathrm{X}$ sejalan Kurikulum 2013, MGMP setiap mata pelajaran dan workshop.

Evaluasi Strategik dalam Meningkatkan Mutu Pendidikan

Komponen terakhir dari manajemen strategis ialah evaluasi dan penilaian perkembangan kemajuan lembaga pendidikan ke arah target strategisnya. Lembaga-lembaga pendidikan yang meyakini bahwa proses dipandang selesai setelah rencana diterapkan hanya akan menemukan diri mereka menemui kegagalan. Penting sekali bagi lembaga pendidikan untuk secara kontinyu meninjau perkembangannya.

Berdasarkan hasil wawancara mendalam penulis dengan kepala sekolah, wakil kepala sekolah, guru-guru, staf, dan komite sekolah serta hasil studi dokumentasi dihasilkan fakta bahwa evaluasi strategik di SMAN 1 Metro Lampung sudah dilaksanakan melalui sejumlah agenda pertemuan dinas, yakni antara kepala sekolah dengan Dinas Pendidikan. Hal ini untuk memperoleh informasi dan kebijakan pendidikan yang berlaku. Rapat bersama kepala sekolah dan komite sekolah serta wakil kepala juga diselenggarakan paling tidak dua kali dalam satu tahun. Rapat khusus kepala sekolah dan wakil kepala sudah dilaksanakan dan bersifat kondisional. Rapat guru, staf, dan kepala sekolah, serta rapat kepanitiaan. Rapat-rapat tersebut dipergunakan oleh SMAN 1 Metro untuk melakukan evaluasi strategi-strategi yang sudah diterapkan. Sekolah dapat melakukan sejumlah langkah perbaikan ke depan agar strategi yang sudah dirumuskan nantinya dapat terlaksana dengan baik.

Menurut Akdon bahwa secara umum terdapat dua jenis evaluasi, yakni: (1) evaluasi formatif yang terdiri dari evaluasi yang dilaksanakan sebelum program dilaksanakan, atau sedang dalam pelaksanaan, atau sesudah program selesai dilaksanakan dan bisa dinilai hasil dan dampaknya, (2). evaluasi sumatif, yaitu evaluasi yang dilaksanakan untuk beberapa tahun atau periode tertentu sehingga membutuhkan pengumpulan data time series bagi beberapa tahun yang dievaluasi (Akdon, 2011: 176-177).

Berdasarkan fakta temuan tersebut, menurut analisis peneliti, terdapat dua jenis evaluasi yang diungkapkan oleh Akdon sudah dilakukan oleh SMAN 1 Metro Lampung yang diteliti, baik evaluasi formatif ataupun evaluasi sumatif. Untuk itu, hasil evaluasi strategik adalah panduan dalam usaha meningkatkan mutu pendidikan dan rencana pengembangan lembaga, dan sekaligus menjadi bahan masukan untuk upaya 
pembinaan dan pengembangan kinerja sekolah sebagai penerapan visi, misi, dan peningkatan mutu sekolah, termasuk dipergunakan sebagai tolok ukur bagi persaingan mutu sekolah pada tingkat internasional, regional, nasional, propinsi, atatupun tingkat kabupaten/kota.

SIMPULAN DAN SARAN

Simpulan

Perencanaan strategik di SMAN 1 Metro Lampung dilaksanakan dengan diawali pembentukan tim perumus, perumusan visi dan misi melalui pertimbangan lingkungan internal dan eksternal, diteruskan dengan penentuan tujuan dan sasaran, kemudian dengan penentuan strategi. Penerapan strategik di SMAN 1 Metro Lampung dilaksanakan dengan menjabarkan sejumlah strategi yang sudah dirumuskan dalam bentuk berbagai kegiatan. Teknis pelaksanaannya diberikan wewenang kepada para koordinator kegiatan dengan tetap melakukan koordinasi dengan kepala sekolah. Sistem pengawasan dilaksanakan dengan menerapkan komunikasi intensif serta pengawasan rutin kepada para koordinator kegiatan. Evaluasi strategik di SMAN 1 Metro Lampung dilaksanakan melalui rapat informal ataupun formal. Rapat formal dilaksanakan secara rutin baik di tingkat internal bidang ataupun secara menyeluruh.

Saran

Visi dan misi sekolah hendaknya bersifat fleksibel diselaraskan dengan perkembangan zaman. Kepala sekolah seyogyanya lebih meningkatkan lagi pengawasan, pemberian reward and punishment untuk meningkatkan kedisiplinan dan meminimalisir penyimpangan manajemen strategik.

\section{DAFTAR PUSTAKA}

Adam, Latif dan Siwage Negara. (2015). Improving human capital through better education to support Indonesia's economic development, economics and finance in Indonesia, 61(2), 2015, 92106.
Akdon. (2011). Strategic management for educational management. Bandung: Alfabeta.

Archibugi, Daniele dan Carlo Pietrobelli. (2003). The globalisation of technology and its implications for developing countries: windows of opportunity or further burden? Technological Forecasting and Social Change, 70(9), 2003, 861-883.

Bryson, John M. (1998). Strategic planning for public and nonprofit organization. San Francisco: Jossey-bass.

Edgerton, Jason D., Lance W. Roberts, Susanne von Below. (2012). Education and quality of life. Dalam Kenneth C. Land, Alex C. Michalos, M. Joseph Sirgy (Eds.), Handbook of Social Indicators and Quality of Life Research. Berlin, Germany: Springer.

Faiz, Mohd, Mohd Yaakob, Muhammad Rushydi Musa, Akhmad Habibi, Roskifzan Othman. (2019). Strategic management and strategic planning in school: is it worth for teachers? Academy of Strategic Management Journal, 18 (3), 2019, 1-6.

Gurley, Keith, Gary B. Peters, Loucrecia Collins, Matthew Fifolt, (2014). Mission, vision, values, and goals: An exploration of key organizational statements and daily practice in schools. Journal of Educational Change, 16 (2), 2014, 1-46.

He, Chuanqi. (2011). Scientific and technological revolution and world modernization: a conjecture and prospect for the sixth scientific and technological revolution. China Center for Modernization Research, Chinese Academy of Sciences, 1 (4), 1-20.

Idrisa, Fazilah, Zaharah Hassana, Azizah Ya'acoba, Saran Kaur Gillb \& Noor Aziah Mohd Awal. (2012). The role of education in shaping youth's national identity. UKM Teaching and Learning Congress 2011, Procedia - Social and Behavioral Sciences, 59, 443-450. 
Khan, Muhammad Wasim Jan dan Muhammad Khalique. (2014). Strategic planning and reality of external environment of organizations in contemporary business environments. Business Management and Strategy, 5(2), 165-182.

Kulsum, Umi. (2013). Rendahnya kualitas pendidikan di Indonesia. Diakses dari jurnalilmiahtp.blogspot.com diakses tanggal 8 November 2019.

Kurniawan, Asep. (2018). Metodologi penelitian pendidikan. Bandung: Remaja Rosdakarya.

Ionescu, Dan Dumitru, Alina Măriuca Ionescu, Elisabeta Jaba. (2013). The investments in education and quality of life. Journal of Knowledge Management, Economics and Information Technology, 2013, 141158.

Murniati, AR, dan N Usman. (2009). Implementasi manajemen stratejik dalam pemberdayaan sekolah menengah kejuruan, Medan: Perdana Publishing.

Nuryakin. (2018). Competitive advange and product innovation: key success of batik SMES marketing performance in Indonesia. Academy of Strategic Management Journal, 17 (2), 2018, 117.

Pournasir, Shahin. (2013). Key success factors of strategic management implementation in SMEs in Iran. Journal of International Studies, 6 (2), 2013, 65-78.

Rohman, Arif. (2012). Kebijakan pendidikan di era desentralisasi. Yogyakarta: Pustaka Pelajar.

Runtuwene, T.L. (2013). Hardiknas, kualitas pendidikan Indonesia rangking 67 dari 127

www.sulut.kemenag.go.id diakses tanggal 1 Desember 2019.

Rustiadia, Sonny. (2015). Creating better education system, building stronger human capital: a creative industries perspective. The 6th Indonesia International Conference on Innovation,
Entrepreneurship and Small Business, 12 - 14 August 2014, Procedia - Social and Behavioral Sciences, 169, 378 386.

Sagala, Syaiful. (2007). Manajemen strategik dalam peningkatan mutu pendidikan. Bandung: Alfabeta.

Syah, Muhibbin. (2004). Psikologi pendidikan: dengan pendekatan baru. Bandung: PT Rosdakarya.

Usman, Husaini. (2013). Manajemen: teori, praktik, dan riset pendidikan. Jakarta: Bumi Aksara.

Walker, Richard, Fariborz Damanpour, Carlos A. Devece. (2010). Management innovation and organizational performance: The mediating effect of performance management. Journal of Public Administration Research and Theory, 20(2), 367-386. 